\title{
The strategic use of auctioning revenues to foster energy efficiency: status quo and potential within the European Union Emissions Trading System
}

\author{
Catharina Wiese $\mathbb{D}$ - Richard Cowart • Jan Rosenow
}

Received: 31 October 2019 / Accepted: 11 August 2020 /Published online: 12 September 2020

(C) Springer Nature B.V. 2020

\begin{abstract}
Auctioning revenues in the European Union Emissions Trading System are likely to increase in the future. This projection is driven by recent changes within the system's framework, which address the current surplus of emission allowances and reduce the overall cap. Considering a growing amount of auctioning revenues, it becomes even more important to assess the use of these revenues and their potential contribution to accelerate decarbonisation efforts. We argue that strategic investments in energy efficiency programmes provide opportunities for realising multiple benefits: additional emission reductions from both ETS and non-ETS sectors, lower economic and societal decarbonisation costs and support for the political process to further tighten the ETS cap. Our assessment of the status of auctioning revenue use at the EU Member State level shows that Member States have made only limited use
\end{abstract}

C. Wiese $(\bowtie)$

Department of Technology, Management and Economics,

Technical University of Denmark, Produktionstorvet 426, 2800 Kongens Lyngby, Denmark

e-mail: catharina.wiese@googlemail.com

R. Cowart $\cdot$ J. Rosenow

The Regulatory Assistance Project, Rue de la Science 23, 1040 Brussels, Belgium

R. Cowart

e-mail: rcowart@raponline.org

J. Rosenow

e-mail: jrosenow@ raponline.org of these multiple benefits in recent years. In 2017, no more than $21.4 \%$ of total revenues have been strategically invested in energy efficiency programmes, as Member States have officially reported to the European Environment Agency's reporting obligations database. However, efficiency programmes funded by auctioning revenues in Germany and Czech Republic present promising cases for the strategic use of auctioning revenues. We conclude that the EU carbon price can provide important signals to investors and energy users, but auctioning revenues can also be a powerful tool in the energy transition and the strategic use of revenues needs to be accelerated in all Member States.

Keywords European Union Emissions Trading System (EU ETS) · Auctioning revenue use · Energy efficiency programmes

\section{Introduction}

Without ambitious energy efficiency targets and a significant increase in energy efficiency investments, the EU will most likely miss even its current 2030 climate target of reducing greenhouse gas (GHG) emissions by $40 \%$ based on 1990 levels, let alone deliver on the commitments made in Paris (Rosenow et al. 2018). ${ }^{1}$ On a global scale, the International Energy Agency (IEA) recently concluded that improvements in enduse energy efficiency could deliver at least $35 \%$ of the total emission reductions needed by 2050 to avoid drastic global climate disruption (IEA 2018). Thus, 
capturing the existing untapped and cost-effective potential for end-use energy efficiency improvements (IEA 2018, Thema et al. 2019) should logically be a major goal of climate policy. However, the EU ETS, Europe's key tool to reduce GHG emissions, is not able to overcome the various non-price barriers to energy efficiency because a carbon pricing instrument alone does not address lack of information, behavioural failures and liquidity constraints (e.g. Cowart 2011). These barriers are commonly considered a major reason for why households and businesses largely fail to invest in cost-effective energy efficiency improvements (Jaffe and Stavins 1994; Gillingham et al. 2009). In Europe, policymakers have recognised these barriers and implemented a number of other policies to address them both through regulatory and financial measures (Rosenow and Kern 2017). The EU ETS has the ability to reinforce EU energy efficiency policy and cost-effective energy efficiency improvements by making use of both the carbon price and the opportunity to recycle auctioning revenues strategically.

The ongoing political discussion on the EU ETS, however, still puts a larger emphasis on the carbon price and its potential to incentivise low-carbon investments. Less attention is paid on how EU Member States spend the revenues that they obtain through the auctioning of EU allowances to companies that are included in the EU ETS and that are required to buy allowances to cover their emissions. Considering that auctioning revenues are an increasing source of income for EU Member States, we propose that it is time to assess the potential contribution of strategic revenue investments to accelerate decarbonisation efforts.

Total auctioning revenues have increased by around $46 \%$ from 2016 to $2017 .^{2}$ The volume of auctioning revenues that EU Member States receive is a function of the number of allowances available for auction and the EU carbon price paid for these allowances (Ecologic Institute and WWF 2016). The EU carbon price has increased from under 5 euros per tonne at the end of 2016 to around 7.5 euros per tonne at the end of 2017 to as high as 25 euros per tonne at the end of $2019 .^{3}$ This

\footnotetext{
2 This increase compares the total auctioning revenues in 2016 and 2017 for all EU Member States but France, which has not reported revenues for 2017 yet, and Bulgaria, which has locked its report for public view in 2016 and 2017. 2016 total revenues without France and Bulgaria amounted to 3.47 billion euros. 2017 total revenues amounted to 5.09 billion euros.

3 e.g. https://markets.businessinsider.com/commodities/co2-europeanemission-allowances (Accessed 08 April 2020)
}

price increase can be attributed to recent changes within the ETS framework and the revision of the EU ETS Directive $^{4}$ : The Market Stability Reserve (MSR) started operating in January 2019 and the linear reduction factor (LRF) will increase from 1.74 to $2.2 \%$ annually from 2021. Addressing the surplus of emission allowances in the EU carbon market and reducing the cap, respectively, both the MSR and the LRF, are expected to have an increasing effect on the EU carbon price and consequently auctioning revenues. The lasting price effect will depend on various additional factors that appear to drive the EU carbon price such as regulatory and political events and investor behaviour (Friedrich and Pahle 2019). The recent changes within the ETS framework and the revision of the EU ETS Directive also affect the number of allowances available for auction. While both the MSR and the LRF reduce the number of allowances available, will the share of free allocations reduce to $30 \%$ until 2026 and reduce to $0 \%$ by 2030 (for sectors not at risk for carbon leakage). A reduction in the number of allowances allocated for free increases the number being auctioned and, thus, will have a positive effect on revenues generated through auctioning.

All of the above affects the volume of auctioning revenues that EU Member States receive. The effect finally depends on the price effect opposed to the volume effect, i.e., the number of allowances available for auction. Yet, projected auctioning revenues show a future increase up to 20 billion euros per year before 2030 (Ecologic Institute and WWF 2016), which also the most recent trends of prices and revenues confirm.

We argue in this paper that strategically investing this growing opportunity into energy efficiency programmes would reinforce the ETS and deliver multiple benefits ${ }^{5}$ :

- Additional emission reductions from sectors both covered by and outside the ETS.

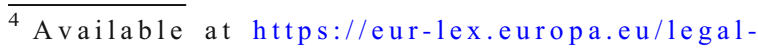
content/EN/TXT/PDF/?uri=CELEX:32018L0410\& from=EN (Accessed 18 December 2018)

${ }^{5}$ The policy mix for reaching decarbonisation targets cost effectively is not limited to energy efficiency policies but also includes, e.g. renewable energy support and research and development for clean technologies, which also overcome some of the limits to carbon pricing and the reliance on a single pricing instrument. However, the economic and societal cost advantages of energy efficiency and the need for funding to stimulate efficiency investments among a large number of end-users make it a particularly important resource to utilise. These are principal justifications for the policies adopted by the EU and other jurisdictions that call for implementing the 'energy efficiency first principle'.
} 
- Lower economic and societal decarbonisation costs by capturing a larger fraction of cost-effective emission reduction potential, which would possibly remain untapped if no additional funding for energy efficiency is made available, and reducing energy bills for end-users.

- A wide range of non-energy benefits from energy efficiency improvements and the resulting demand reduction. Among those benefits are improvements in health, comfort, air quality, job creation and economic growth.

- Support for the political process to further tighten the EU ETS cap. An increase in the political will and social acceptance, as a result of the previous benefits, can enable more ambitious long-term decarbonisation targets.

The aim of this paper is to present detailed data on the current status in Europe regarding carbon revenue recycling and to demonstrate why increasing the share of carbon revenues that are recycled for energy efficiency investments is desirable from a carbon perspective. The paper is structured as follows: 'Background: the economic case for investing auctioning revenues in energy efficiency' introduces why investing auctioning revenues in energy efficiency would further reduce emissions at lower economic and societal costs. In 'Status quo of auctioning revenue use at the EU Member State level', we present our assessment of auctioning revenue use at the EU Member State level. The assessment includes additional information on auctioning revenue use in Germany and the Czech Republic, which we identify as exceptional cases. 'Discussion: interactions among the EU ETS, auctioning revenue use and energy efficiency improvements' discusses interactions between energy efficiency improvements and the EU ETS, and 'Conclusion' concludes. ${ }^{6}$ Parts of this paper have been presented at the

\footnotetext{
${ }^{6}$ While this paper presents and focuses on the rationale and evidence for investing EU ETS auctioning revenues in cost-effective energy efficiency measures, the topic of reinvesting carbon revenues could also be relevant on a broader scale. The European Commission and Parliament as well as individual Member States are currently considering a range of energy policies and tax reforms that could also yield new revenues. These include the carbon border adjustment mechanism proposed in the European Green Deal, carbon floor prices adopted or under discussion in Member States, extending the ETS to the buildings and transport sectors and revising the energy taxation directive (e.g. European Commission 2019c; Euractiv 2020).
}

ECEEE 2019 Summer Study on 'Energy efficiency first, but what next?' (Wiese et al. 2019).

\section{Background: the economic case for investing auctioning revenues in energy efficiency}

Strategically investing auctioning revenues in energy efficiency measures can make a relevant contribution to achieve emission reductions at the lowest economic and societal costs. Some economists would strictly disagree with this proposition, defining external costs of GHG emissions as the only market failure to address. In a first-best setting, a single carbon pricing instrument as the EU ETS would, in theory, internalise the externality and effectively incentivise emission reductions, while any policy on top would distort market forces (e.g. Barranzini et al. 2017).

However, others acknowledge the existence of second-best problems, e.g. market failures and/or exogenous real-world constraints, which rationalise the use of multiple policies with a common policy target (e.g. Bennear and Stavins 2007). Also the EU has taken a different position, adopting mandates for renewable energy and efficiency in addition to the EU ETS. Investing auctioning revenues to further strengthen EU energy efficiency policy could reinforce the EU ETS and reduce the economic and societal costs of GHG emission reductions, because:

1. Investing auctioning revenues in energy efficiency can help to realise a larger fraction of cost-effective emissions reduction potential. Recent evidence shows that there exists a large and untapped potential for cost-effective energy efficiency improvements in EU Member States (Thema et al. 2019). Realising this potential would accelerate GHG emission reductions and, because it is costeffective and would save more than it would cost in many instances, reduce the economic cost of reaching decarbonisation targets. The potential remains untapped due to various barriers to energy efficiency, which includes imperfect and asymmetric information, principal agent problems, behavioural failures and limited access to capital. It is well established that in the markets for energy efficiency, market failures and barriers beyond the negative externality of energy production and consumption exist. These barriers keep energy end-users from 
investing in cost-effective energy efficiency improvements and are a major justification for public policy interventions that implement multiple policies (Jaffe and Stavins 1994; Gillingham et al. 2009). By definition, non-price barriers to energy efficiency cannot be overcome by a pricing policy alone; i.e., due to other real-world constraints, a carbon price cannot unlock all longterm, cost-effective energy saving and thus GHG emissions reduction potential. Therefore, energy efficiency programmes that address the behavioural, financial and legal barriers to energy efficiency are needed in order to make use of a greater fraction of the cost-effective emissions reduction potential.

2. Investing auctioning revenues in energy efficiency would reduce the energy bill impacts of carbon pricing on energy end-users. The EU allowance price paid by power and heat generators has a disproportionate and negative effect on consumer energy bills. A calculation of the consumer cost per tonne of abatement in competitive power markets shows that the cost to consumers per tonne of carbon reduced can be several times larger than the market price of carbon allowances (Cowart 2011). According to a study from Cambridge Econometrics and the Energy Centre of the Netherlands (2013), a carbon price of 20 euros per tonne impacts the merit order of dispatch in wholesale power markets in such a way that it yields a cost to power consumers amounting to 248 euros per tonne avoided, assuming nil price elasticity. ${ }^{7}$ The study furthermore shows that greater support for investments in end-use energy efficiency would reduce energy demand, which a pricing instrument alone would only achieve to a limited degree considering low energy price elasticities, specifically in the short run. The reduction in energy demand due to greater support for investments in end-use energy

\footnotetext{
${ }^{7}$ This calculation is based on the power price increases due to carbon pricing, i.e. the extra cost to consumers and the avoided tonnes of GHG emissions due to the impact on the merit order of dispatch (Cowart 2011). Note: Although the modelling timeframe in the study from Cambridge Econometrics and the Energy Research Centre of the Netherlands (2013) was set to 2020, the analysis of interactions between cap reductions, carbon prices, emissions and end-use energy efficiency are still relevant and provide meaningful results at all timescales.
}

efficiency would reduce GHG emissions and consumer energy bills due to lower prices on wholesale power markets. ${ }^{8}$ Particularly if energy efficiency investments are geared towards low-income households, this would potentially increase the public acceptability of carbon pricing, an issue that is often underappreciated by theoretical economic analysis (Rabe 2016, 2018). Analyses of real-world examples of carbon pricing (and revenue recycling) regimes demonstrate that public acceptability is of high importance for the long-term success of carbon pricing policies (Klenert et al. 2018). If targeted effectively, earmarked revenues can deliver significant benefits to specific communities or demographics. Revenues can be used, for example, to directly compensate for the cost of the tax or to support programmes that reduce energy costs for low-income households, (through energy efficiency or renewable energy), expand public infrastructure (e.g. transport), create economic stimulus in transition regions or reduce local pollution in disadvantaged communities. Among mechanisms to offset the impact of a carbon price on consumers, the most frequently used are those that directly compensate for additional costs associated with the carbon price. Consumers are compensated through the return of carbon revenue through a variety of means such as a lump-sum cashback or the reduction of income, employment or capital taxes. Depending on the design, these approaches have been more or less effective at levelling negative distributional effects. Cashback to all consumers is generally evaluated to be more progressive (benefiting proportionally more households on low incomes) than redistribution through tax adjustments (Cunha Montenegro et al. 2019). Returning revenues to energypoor households and vulnerable communities is an important and equitable means to offset the cost burden imposed by a carbon price in the short term. However, returning the majority of revenues back to all consumers is an

\footnotetext{
$\overline{{ }^{8} \text { The wholesale }}$ power price is lower due to the demand reduction for energy and EU allowances. Both demand reductions have a lowering effect on the clearing price on competitive power markets.
} 
ineffective strategy to meet overall carbon goals. Returning all revenues to consumers relies solely on the price impact to drive down emissions; as has been illustrated, carbon prices would have to be unrealistically high to drive deep change. Together with targeted cashback or bill support for low-income households, recycling of revenues into efficiency and renewable energy programmes targeted to lowincome households or communities reduces bills significantly in the long term. This investment can tackle the significant challenges of reducing energy poverty and accelerating decarbonisation in hard-tochange sectors such as housing and transport. France, for example, reports that it invests parts of its auctioning revenues into the Habiter Mieux programme (Agence nationale de l'habitat (ANAH), 2020), which funds building renovations for lowincome and energy-poor households. There is evidence that this rationale may be gaining ground with new taxes that have been recently announced coupled with ring-fenced support for low-income and energy-poor households and earmarking for clean energy transition programmes (e.g. in 2019 in Ireland (Press Association 2019) and Luxembourg (Euractiv 2019)).

Both rationales make clear why using auctioning revenues to support energy efficiency measures complementary to the EU ETS would reduce the economic and societal costs of decarbonisation. Energy efficiency is a key to capturing cost-effective energy and emission reduction potentials, while minimising rate and cost impacts. ${ }^{9}$

\section{Status quo of auctioning revenue use at the $\mathbf{E U}$ Member State level}

Article 10(3) of the EU ETS Directive 2003/87/EC recommends that Member States should use at least

\footnotetext{
${ }^{9}$ Note: We do not want to claim that using auctioning revenues is inherently better than other ways to fund energy efficiency. However, there are at least two reasons to promote it: (i) It is aligned with the whole goal of the EU ETS, which is to reduce emissions at lowest practicable cost and should thus be viewed as integral to the design of the EU ETS, just like the LRF or the MSR. (ii) As a matter of practical politics, making the revenue available via a dedicated revenue stream avoids the problems of stop-and-go funding when energy efficiency relies on annual appropriations.
}

$50 \%$ of auctioning revenues or the equivalent in financial value of these revenues for energy- and climaterelated purposes. These purposes are specified in Art. 10(3) and Art. 3d(4) and include a range of options: further GHG emission reductions in EU and third countries, the development of renewable energies, measures to increase energy efficiency, shift to low emission and public forms of transport and administrative policy expenses. ${ }^{10}$

Since 2013, a mechanism for reporting on the use of auctioning revenues ${ }^{11}$ requires Member States to report annually (for the first time by July 2014) on the amounts of revenue generated through the auctioning of allowances and the use of these revenues or the equivalent in financial value. Member States shall specifically report the purpose and type of revenue use for energy- and climate-related programmes, domestic and international. ${ }^{12}$ The following section assesses the national reports submitted by 31 July 2018, reporting the use of auctioning revenue for $2017 .^{13}$

Assessment of the Member States' reporting on the use of 2017 auctioning revenues

In 2017, EU Member States received 5.09 billion euros through the auctioning of emission allowances in the EU ETS. ${ }^{14}$ Altogether, the reporting shows that Member States used or planned to use 4.07 billion euros $(80.0 \%)$ of the total amount of 2017 revenues or the equivalent in financial value for energy- and climaterelated purposes. This relatively high share is consistent with the findings of reports on the use of auctioning revenues from previous years (Ecologic Institute and

\footnotetext{
${ }^{10}$ Art. 10(3) and Art. 3d(4) of Directive 2003/87/EC provide a more detailed list of eligible purposes. Retrieved from: https://eur-lex. europa.eu/legal-content/EN/TXT/PDF/?uri=CELEX:02003L0087$20140430 \&$ from $=$ EN.

${ }^{11}$ Specified in Art. 17 of Regulation (EU) No 525/2013. Retrieved from https://publications.europa.eu/en/publication-detail//publication/4bf8306c-dab2-4fa0-8c83-8d44d760b31f/language-en

${ }^{12}$ International use comprises funding of multilateral (e.g. United Nations Framework Convention on Climate Change (UNFCCC) Green Climate Fund) or bilateral programme support.

${ }^{13}$ Member states submit their reports to the European Environment Agency's reporting obligations database (ROD), part of the European Environment Information and Observation Network (EIONET). Deliveries are available at http://rod.eionet.europa.eu/obligations/698 /deliveries (Accessed 09 January 2019).

${ }^{14}$ This amount of 2017 auctioning revenues and the further assessment of the Member States' reporting do not include France, which has not reported its revenues for 2017 yet, and Bulgaria, which has locked its report for public view.
} 
WWF 2016; Le Den et al. 2017; Wiese et al. 2018). A recent report by the European Commission reveals that the share of revenues used or planned to be used for energy- and climate-related purposes went down to $70 \%$ in 2018, where total revenues were around 14 billion euros (European Commission 2019a). However, it is worth noting that these calculations include Member States that do not earmark auctioning revenues for specific uses but still report the equivalent in financial value used for energy and climate purposes from their national budgets.

Strictly speaking, these Member States do not strategically invest their auctioning revenues, i.e. they do not directly use, in other words earmark, them for energy and climate purposes. Excluding Member States that do not earmark auctioning revenues for specific uses, the reported strategic investments reduce to 2.81 billion euros, equivalent to $55.3 \%$ of total 2017 revenues. The share of revenues not strategically invested in energy and climate purposes, $44.7 \%$, includes the use of auctioning revenues that Member States do not specify ( 0.60 billion euros) and all revenues from states that do not earmark (1.67 billion euros). These amounts are not strategically reinvested but allocated to the national budgets. The further assessment of Member States' auctioning revenue use therefore considers only the use of earmarked revenues and excludes Member States that do not earmark. For 2017 revenues, the national reports from Austria, Denmark, Finland, Luxembourg, the Netherlands, Poland, Sweden, Ireland and the UK indicate that these Member States do not earmark auctioning revenues for specific uses.

All other Member States, except Romania, report to invest some share of their auctioning revenues for domestic or international energy- and climate-related purposes ranging from $12 \%$ in Cyprus to $116 \%$ in Malta. ${ }^{15}$ On an aggregate level, the national reports reveal that these Member States use $21.4 \%$ of total 2017 revenues to finance energy efficiency measures, $16.7 \%$ to promote renewable energy, $4.9 \%$ for other domestic/EU uses, and $4.2 \%$ to support the shift to low-emission

\footnotetext{
${ }^{15}$ Romania reports to use $0 \%$ of their 2017 auctioning revenue for energy- and climate-related purposes, while Malta reports to use a higher amount for energy- and climate-related purposes than their total auctioning revenue. This difference might occur due to the use of carryover revenues from years before 2017. However, the reported data provides no further explanation.
}

and public forms of transport. The remaining $8.1 \%$ (summing to $55.3 \%$ strategically invested 2017 revenues) are spread over various energy- and climaterelated purposes (see footnote 15).

A significantly larger share of Member States' strategic investments is used domestically (126.9\%), while only a small share is spent for international use $(6.2 \%)$. We therefore continue focusing on Member States' domestic use of auctioning revenues. The assessment of domestically used revenues reveals the challenge of heterogeneity among Member States' way of reporting: Germany indicates to use $100 \%$ of its total 2017 revenues for energy- and climate-related purposes (1.15 billion euros). However, it reports the total spending of its national energy and climate fund for different domestic types of use (2.05 billion euros). Thus, only $56 \%$ of the fund's total spending is financed through auctioning revenues. Germany's way of reporting largely explains why more than $100 \%$ of strategically invested 2017 revenues are reported to be used domestically $(126.9 \%)$. In order to present an accurate figure for the domestic use of auctioning revenues, we have removed Germany's non-ETS funds from the analysis. We have adjusted its domestic use, setting it equal to $100 \%$ total revenue in 2017 , and applied the ratios of domestic types of use to this amount. ${ }^{16}$

Figure 1 shows how Member States use their earmarked auctioning revenues domestically as a share of total earmarked and domestically reinvested revenues, distinguishing different types of use.

The largest share of domestically used auctioning revenues $(40.8 \%=1.09$ billion euros) finances energy efficiency measures, followed by the promotion of renewable energy $(31.9 \%=0.85$ billion euros), other domestic/EU uses $(9.4 \%=0.25$ billion euros $)$ and the

\footnotetext{
${ }^{16}$ We are aware that this approach only gives an approximation of Germany's auctioning revenue use; however, the available data does not allow for more detailed conclusions. The analysis of domestic use required the following additional data processing: (1) interpretation of committed versus disbursed spending on a country-by-country basis. Some Member States report both committed and disbursed amounts, with the disbursed amounts being included in the committed amounts, while other Member States report both amounts separately. (2) Where Member States report ambiguous domestic types of use or the reported type does not match the purpose of revenue use (i.e. specific programme support), we took a further look at the individual programmes, if provided, to categorise the Member States' domestic use.
} 
shift to low emission and public forms of transport $(8.1 \%=0.22$ billion euros $){ }^{17}$

A total of $59.2 \%$ of the total domestic use for energy efficiency in the EU as a whole comes from German auctioning revenues (with adjustment). Yet, also Belgium, Czech Republic, Croatia, Hungary, Italy and Latvia report to strategically invest between 50 and $100 \%$ of their domestic use of auctioning revenues in energy efficiency. We identified two exceptional cases: Germany reports the highest 2017 auctioning revenues of all EU Member States and thus with a high share supporting energy efficiency measures, it contributes significantly to the total reported use for energy efficiency. In the Czech Republic, the strategic use of auctioning revenues is a well-established practice. The Czech New Green Savings Programme has been funded by auctioning revenues since its programme launch in 2013, and auctioning revenues are considered a major source for energy efficiency finance. Furthermore, the programmes partially funded by auctioning revenues in these countries have been shown to deliver energy savings and GHG emissions reductions, cost savings to consumers, tax revenue to the national budgets, employment and economic growth (Department of Communications, Climate Action, and Environment 2017; Diefenbach et al. 2018; Zámečník and Lhoták 2012; Ministry of Industry and Trade 2017). Table 1 provides further information on the supported programmes in Germany and Czech Republic.

\section{Critical review of Member States' revenue data}

Our assessment uses the Member States' official reporting on the use of 2017 auctioning revenues. The reporting is mandatory; however, it is the Member States' own responsibility to report, and there is no external verification of the reported numbers. Thus, the assessment requires some degree of reliance on the

\footnotetext{
$\overline{17}$ The aggregated use category includes funding of research and development $(\mathrm{R} \& \mathrm{D})$ for clean technologies and energy efficiency (1.0\%), of $\mathrm{R} \& \mathrm{D}$ and demonstration projects for reducing emissions and for adaptation $(0.1 \%)$, other reductions of GHG emissions $(0.2 \%)$, forestry sequestration in the Union $(0.1 \%)$, adaptation to the impacts of climate change (1.0\%), cross-cutting measures $(2.0 \%)$ and coverage of administrative expenses of the management of the ETS scheme $(0.3 \%)$. These investment categories are officially listed as energy- and climaterelated purposes in the EU ETS Directive. We have added the category 'cross-cutting measures', in case multiple purposes have been reported for the same amount of spending and aggregated the categories for which only a small share of domestic revenues is used in order to ensure a clearer presentation in Fig. 1.
}

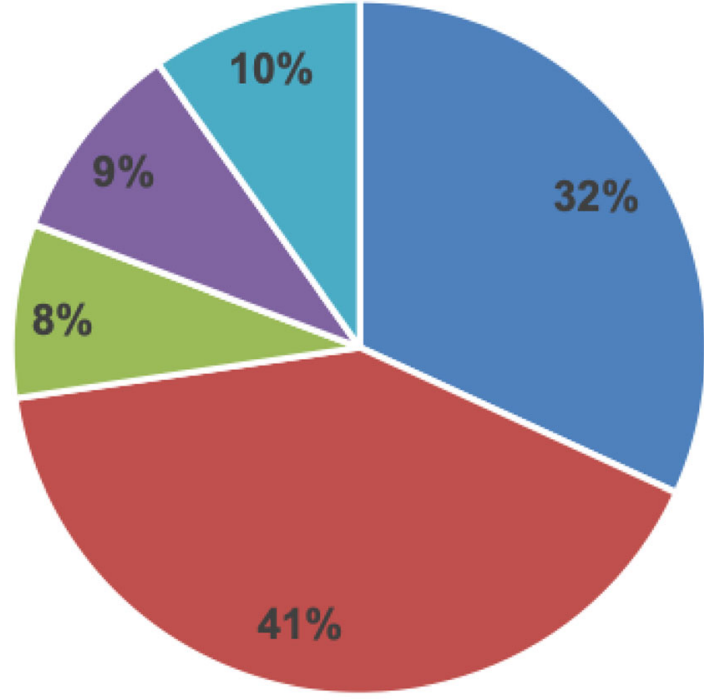

- Renewable energy

- Energy efficiency

- Low-emission and public transport

- Other domestic / EU uses

- Aggregated use

Fig. 1 Domestic types of auctioning revenue use as a share of total domestic use of auctioning revenues in EU Member States

states' submissions. The following points should be discussed:

- Although the quality of reporting has improved since the introduction of the reporting scheme, it still varies across Member States. Thus, there is a need for more transparent and granular reporting, which should ideally also include a requirement for independent monitoring and verification of the reported uses.

- The reporting does not allow to draw conclusions whether the use of auctioning revenues for energy efficiency in some Member States has led to additional programme support, as it would require a counterfactual without the revenue income stream. Future research could estimate the additional impact of auctioning revenues on efficiency programmes by comparing trends in funding levels before and after the revenues were assigned to certain programmes and by studying their political and administrative histories.

- Slovakia, Belgium, Greece and Germany report to use a share of their total domestically reinvested 
Table 1 The use of auctioning revenues for energy efficiency in Germany and Czech Republic

\begin{tabular}{|c|c|c|}
\hline Member State & $\begin{array}{l}\text { Domestically invested revenues } \\
\text { for energy efficiency }\end{array}$ & Energy efficiency investment \\
\hline Germany & $\begin{array}{l}0.64 \text { billion euros (adjusted); } \\
56 \% \text { of adjusted domestic use in Germany }\end{array}$ & $\begin{array}{l}\text { Energy and Climate Fund: supports various energy efficiency } \\
\text { programmes, such as the KfW support scheme in the building } \\
\text { sector, energy-saving measures implemented through the } \\
\text { 'Energieeffizienzfond', the tender scheme 'STEPup!' for industrial } \\
\text { energy-saving investments and the 'Anreizprogramm } \\
\text { Energieeffizienz' for the replacement of heating and ventilation systems }\end{array}$ \\
\hline Czech Republic & $\begin{array}{l}0.01 \text { billion euros; } \\
50 \% \text { of total domestic use in } \\
\text { Czech Republic }\end{array}$ & $\begin{array}{l}\text { New Green Savings Programme: a financial support scheme } \\
\text { designed to promote energy savings in single-family, multi-family } \\
\text { and public sector buildings, focusing on the renovation of existing } \\
\text { buildings, construction of new buildings with low-energy standard } \\
\text { and utilisation of low-emission or renewable sources for heating } \\
\text { EFEKT Programme: a financial support scheme designed to } \\
\text { promote energy-saving measures and renewable energy sources } \\
\text { among small customers, focusing on energy efficiency } \\
\text { improvements, energy management and awareness raising } \\
\text { through education }\end{array}$ \\
\hline
\end{tabular}

revenues for electricity price compensation to energy-intensive industry at risk for carbon leakage. Slovakia disbursed and committed around $50 \%$ of its total domestic use of auctioning revenues to compensation payments (20 million euros), Belgium around 30\% (39 million euros), Greece around 15\% (30 million euros) and Germany around 14\% (160 million, adjusted). This list includes all Member States that report to strategically reinvest auctioning revenues and to use a certain share of their revenues for compensation payments. The list, however, is not a complete list of all Member States that provide compensation payments financed through some national budget. ${ }^{18}$ Although the use of auctioning revenues for compensation payments is permitted to count as an energy- and climate-related purpose under EU rules, it certainly decreases the beneficiaries' motivation to reduce their energy consumption. Instead, using revenues to improve energy efficiency at such industries could improve their competitiveness while also reducing emissions.

- The economic report of Germany's energy and climate fund (for 2017) shows that a large fraction of money (approximately 40\%) committed to support energy and climate programmes was not disbursed for actual use (Zeitung für Kommunale Wirtschaft 2018). This case shows that the

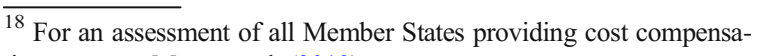
tion, see, e.g. Marcu et al. (2019).
}

provision of financial resources is one important step; however, it does not solve the challenge to overcome all other barriers to energy efficiency.

\section{Discussion: interactions among the EU ETS, auctioning revenue use and energy efficiency improvements}

The recent changes within the ETS framework are intended to address the current surplus of emission allowances and reduce the overall cap (MSR and LRF, respectively). These changes are expected to increase future EU allowance prices and the incentive to reduce emissions. The impact on auctioning revenues is not straightforward: In the first instance, lowering the number of allowances available in the system would, ceteris paribus, lower total available revenues. On the other hand, a tighter market increases the carbon price, and the gradual elimination of free allocations also tends to drive up total auctioning revenues. As mentioned before, projections indicate that total auctioning revenues across the EU might increase up to 20 billion euros per year before 2030 (Ecologic Institute and WWF 2016). If Member States continue to devote the same fraction of auctioning revenues to efficiency programmes as reported in 2017, higher revenues would increase the amount of revenues used for energy- and climate-related purposes and increase the income stream available for energy efficiency programme support. 
The interaction between the EU ETS and improved energy efficiency, expecting higher (and ideally incremental) support for complementary energy efficiency measures, is more complex and often debated among researchers and policy advisers. ${ }^{19}$ If energy efficiency programmes have the effect of lowering demand for allowances by reducing energy consumption and generation (covered by the ETS, i.e. electricity), the carbon price would reduce. Freed-up allowances would be banked for later use or would be sold to other emitters, meaning that the efficiency programmes would not achieve emission reductions under the cap-and-trade system but only reduce the price and thus the cost to businesses and consumers of complying with the cap. The carbon price reduction would furthermore hamper the capacity of the EU ETS to incentivise low-carbon investments.

While critics have frequently used this 'waterbed effect' to argue against the implementation of measures that would reduce emissions additional to the EU ETS, we start with the argument that the overriding rationale of carbon cap-and-trade systems is, indeed, to uncover the lowest-cost opportunities to reduce emissions and therefore to reduce the price of carbon. Thus, any action to reduce emissions within a cap-and-trade system will intentionally release emissions allowances into the market and reduce pressure on the carbon price without directly reducing the cap. In other words, the 'waterbed effect' is an essential design element of cap-and-trade systems. It is therefore inconsistent with cap-and-trade theory to criticise additional policies, such as efficiency programmes, merely because they may reduce carbon prices under a cap.

We emphasise three further interactions between energy efficiency improvements and the EU ETS, taking into account where revenues are currently invested, why the revised ETS framework 'punctures the waterbed' and how future revisions could further reinforce the major objective of the EU ETS to reduce emissions cost effectively:

- Some Member States use their auctioning revenues to improve the thermal efficiency in buildings and add insulation to homes, reducing energy

\footnotetext{
$\overline{19}$ This debate is not limited to energy efficiency improvements but even more established with respect to increased adoption of renewable energy sources (e.g. Del Río González 2007) and starts to include policy changes on the national level, e.g. coal phase-out proposals (Ecofys 2016).
}

consumption of natural gas, fuel oil or district heat systems that are largely outside the ETS. In this way, the cap-and-trade scheme can drive reductions outside, and in addition to, the reductions mandated by the cap. This approach is especially useful when it would be impracticable or politically infeasible to bring those sectors into the cap regime.

- Considering the large amount of surplus allowances built-up in the EU ETS and the introduction of the MSR, the argued 'waterbed effect' is punctured (Sandbag 2017; Perino 2018). From 2019 to 2028, the MSR is expected to take in approximately 1.8 billion allowances (additional to the initial transfer of unallocated and back-loaded allowances from phase 3). Moreover, allowances in the MSR are limited in their validity. Therefore, a substantial number, up to 2.4 billion, is expected to be cancelled in 2023 (Marcu et al. 2018). With the MSR in operation, complementary measures that reduce the demand for allowances increase the surplus, of which a large proportion will eventually be cancelled. Thus, freed-up allowances and finally emissions are not simply shifted in space and time, as supposed by the 'waterbed effect' argument, but added to the existing surplus on the EU carbon market. $^{20}$

- With respect to future revisions of the ETS framework, success in the strategic use of auctioning revenues for energy efficiency, which lowers energy bills along with emissions, could be used to support the political process to tighten the cap (Cowart et al. 2015). There is ample evidence from multiple jurisdictions that carbon pricing enjoys a much higher level of support among economists than it does across the general public, and many observers doubt that carbon pricing can, by itself, attract sufficient public support to drive down emissions enough to meet global carbon targets (Rabe 2016, 2018). However, the public's willingness to support carbon pricing is greatly enhanced where the revenue would be directed towards programs to reduce emissions, especially renewable energy

\footnotetext{
${ }^{20}$ The ability of the MSR to absorb the impact of complementary policies on the supply and demand imbalance and the carbon price effect are, however, still uncertain and rely on potential adjustments after the MSR reviews scheduled for 2021 and 2026. The opposite MSR mechanism to release allowances to the market when a lower threshold of allowances in circulation is reached is not expected to be utilised before 2030 (Marcu et al. 2018).
} 
(Fowlie 2019). The nine states comprising the RGGI cap-and-trade scheme in the north-eastern USA advanced this idea further, using most of the auction revenues to support energy efficiency programs among end-users - not just reducing emissions but directly lowering many consumers' bills as well as the cost of electricity generally. ${ }^{21}$ As a result, while several nations, states and provinces from Australia to Ontario have reversed course and abandoned carbon pricing, the RGGI states have twice renewed the RGGI programme and significantly lowered the regional cap. By turning the carbon price 'penalty' into a tool to support public benefits, RGGI demonstrates the political value of carbon revenue recycling to sustaining carbon pricing as a climate mitigation tool (Raymond 2016).

\section{Conclusion}

Strategically investing auctioning revenues in end-use energy efficiency provides an increasing opportunity for Member States to reinforce the EU ETS. Support for complementary energy efficiency programmes can yield multiple benefits because energy efficiency improvements help to deliver cost savings and emissions reductions, reduce the upward pressure on consumer energy bills and realise the energy and non-energy benefits of end-use energy efficiency. Furthermore, in practical political terms, the multiple benefits from strategic investments can be substantial. To achieve the targets of the Paris agreement and avoid drastic global climate disruption, climate policies must deliver GHG emission reductions sustainably over decades of progress, which, in modern democratic societies, requires sustained political support. Public support for climate policies will be easier to maintain when the consumer costs of carbon pricing are moderate and the policy is seen to deliver cost savings to end-users, not primarily higher prices across the board.

In the EU ETS, the potential to use these benefits is to a large extend still untapped. Some Member States strategically invest their auctioning revenues in

\footnotetext{
${ }^{21}$ Through 2017, RGGI states allocated $58 \%$ of revenues to energy efficiency, $14 \%$ to clean and renewable energy, $14 \%$ in direct bill assistance and $8 \%$ to other GHG abatement measures (Regional Greenhouse Gas Initiative, Inc. 2019).
}

energy- and climate-related programmes. The fundamental understanding that both the carbon price and the strategic use of revenues can help to achieve the EU's decarbonisation targets cost-effectively is, however, limited. Our assessment of the Member States' use of auctioning revenues shows that in $2017,44.7 \%$ of total revenues are strategically invested for energy- and climate-related purposes, no more than $21.4 \%$ in energy efficiency programmes.

A recent assessment of Member States' National Energy and Climate Plans by the European Commission revealed that a majority of Member States needs to increase energy efficiency efforts in order to achieve the EU's energy and climate targets (European Commission 2019b). Earmarking auctioning revenues can help to increase and stabilise the amount of financial resources that are available to finance energy efficiency policies given that auctioning revenues do not simply replace other financial resources. Further establishing the strategic use auctioning revenues requires a broader political and scientific debate on the EU ETS and its ability to reduce greenhouse gas emissions cost-effectively, including both the carbon price and carbon revenues.

Funding The research has been financed by the Innovation Fund Denmark under the research project SAVE-E, grant no. 4106-00009B.

\section{Compliance with ethical standards}

Conflict of interest The authors declare that they have no conflict of interest.

\section{References}

Agence nationale de l'habitat (ANAH) (2020) (online resource). Retrieved from: www.anah.fr/proprietaires/proprietairesoccupants/etre-mieux-chauffe-avec-habiter-mieux/. Accessed 11 Sept 2020.

Barranzini, A., van den Bergh, J., Carrattini, S., Howarth, R., Padilla, E., \& Roca, J. (2017). Carbon pricing in climate policy: seven reasons, complementary instruments, and political economy considerations. WIREs Climate Change, $8(4)$.

Bennear, L. S., \& Stavins, R. N. (2007). Second-best theory and the use of multiple policy instruments. Environmental and Resource Economics, 37(1), 111-129. 
Cambridge Econometrics and the Energy Research Centre of the Netherlands (2013). Investing EU ETS auction revenues into energy savings. Retrieved from: https://publications.tno. nl/publication/34629216/k8ac50/e13033.pdf.. Accessed 11 Sept 2020.

Cowart, R. (2011). Prices and policies: carbon caps and efficiency programmes for Europe's low-carbon future. ECEEE 2011 Summer Study. Retrieved from: https://www.eceee. org/library/conference proceedings/eceee Summer Studies/2011/. Accessed 11 Sept 2020.

Cowart, R., Bayer, E., Keay-Bright, S., \& Lees, E. (2015). Carbon Caps and Efficiency Resources: Launching a "Virtuous Circle" for Europe. Retrieved from: https://www.raponline. org/knowledge-center/. Accessed 11 Sept 2020.

Cunha Montenegro, R., Lekavičius, V., Brajković, J., Fahl, U., \& Hufendiek, K. (2019). Long-term distributional impacts of European cap-and-trade climate policies: a CGE multiregional analysis. Sustainability, 11, 6868.

Del Río González, P. (2007). The interaction between emissions trading and renewable electricity support schemes. An overview of the literature. Mitigation and Adaptation Strategies for Global Change, 12(8), 1363-1390.

Department of Communications, Climate Action \& Environment (2017). National Energy Efficiency Action Plan for Ireland 2017-2020. Retrieved from: https://ec.europa. eu/energy/sites/ener/files/documents/ie_neeap_2017.pdf. Accessed 11 Sept 2020.

Diefenbach, N, Stein, B., Loga, T., Rodenfels, M., \& Jahn, K. (2018). Monitoring der KfW-Programme „Energieeffizient Sanieren“ und „Energieeffizient Bauen“ 2017. Retrieved from: ht t p s : / / w w w. kfw. d e / K f W Konzern/Newsroom/Aktuelles/News-Details_498497.html. Accessed 11 Sept 2020.

Ecofys. (2016). The waterbed effect and the EU ETS: an explanation of a possible phasing out of Dutch coal fired power plants as an example.

Ecologic Institute and WWF (2016). Smart Cash for the Climate: Maximising Auctioning Revenues from the EU Emissions Trading System. Retrieved from: https://www.ecologic. eu/sites/files/publication/2016/2596-smartcashforclimatefull-report_0.pdf. Accessed 11 Sept 2020.

Euractiv (2019). Luxembourg to deploy carbon tax from 2021. Retrieved from: www.euractiv.com/section/climateenvironment/news/luxembourg-to-deploy-carbon-tax-from2021/.

Euractiv (2020). France calls for carbon price floor to counter oil crash. Retrieved from: www.euractiv.com/section/emissionstrading-scheme/news/france-calls-for-carbon-price-floor-tocounter-oil-crash/.

European Commission (2019a). Report from the Commission to the European Parliament and the Council: Report on the functioning of the European carbon market. Retrieved from: https://eur-lex.europa.eu/legal-content/EN/TXT/?uri= COM:2019:0557:FIN. Accessed 11 Sept 2020.

European Commission (2019b). Communication from the Commission to the European Parliament, the Council, the European Economic and Social Committee and the Committee of the Regions: United in delivering the Energy Union and Climate Action - Setting the foundations for a successful clean energy transition. Retrieved from:
https://eur-lex.europa.eu/legal-content/EN/TXT/?uri= CELEX\%3A52019DC0285. Accessed 11 Sept 2020.

European Commission (2019c). Communication from the Commission to the European Parliament, the European Council, the Council, the European Economic and Social Committee and the Committee of the Regions: The European Green Deal. Retrieved from: https://ec.europa. eu/info/sites/info/files/european-green-deal-communication en.pdf. Accessed 11 Sept 2020.

Fowlie, M. (2019). The Trouble With Carbon Pricing. Energy Institute at Haas. Retrieved from: https://energyathaas. wordpress.com/2019/04/29/the-trouble-with-carbonpricing/.. Accessed 11 Sept 2020.

Friedrich, M., \& Pahle, M. (2019). Allowance Prices in the EU ETS - Fundamental Price Drivers and the Recent Upward Trend. Working Paper, Potsdam Institute for Climate Impact Research. Retrieved from: https://www.pik-potsdam. $\mathrm{d}$ e / r e s e a c h/t r a n s f o r m a t i o n pathways/projects/ahead/scientfic-articles. Accessed 11 Sept 2020.

Gillingham, K., Newell, R. G., \& Palmer, K. (2009). Energy efficiency economics and policy. Annual Review of Resource Economics, 1(1), 597-620.

IEA. (2018). Energy efficiency 2018: analysis and outlooks to 2040. Paris: International Energy Agency Retrieved from: http://www.oecd.org/publications/energy-efficiency-20189789264024304-en.htm. Accessed 11 Sept 2020.

Jaffe, A. B., \& Stavins, R. N. (1994). The energy-efficiency gap: What does it mean? Energy Policy, 22(10), 804-810.

Klenert, D., Mattauch, L., Combet, E., Edenhofer, O., Hepburn, C., Rafaty, R., \& Stern, N. (2018). Making carbon pricing work for citizens. Nature Climate Change, 8, 669-677.

Le Den, X., Beavor, E., Porteron, S., \& Ilisescu, A. (2017). Analysis of the use of auction revenues by the Member States. Retrieved from: https://ec.europa. $\mathrm{eu} / \mathrm{clima} / \mathrm{sites} / \mathrm{clima} /$ files/ets/auctioning/docs/auction revenues_report_2017_en.pdf. Accessed 11 Sept 2020.

Le Quéré, C., Jackson, R. B., Jones, M. W., et al. (2020). Temporary reduction in daily global $\mathrm{CO}_{2}$ emissions during the COVID-19 forced confinement. Nature Climate Change, 10, 647-653.

Marcu, A., Alberola, E., Caneill, J-Y., Mazzoni, M., Schleicher, S.P., Stoefs, W., Vailles, C., \& Vangenechten, D. (2018). 2018 State of the EU ETS Report. Retrieved from: https://www.i4ce.org/download/2018-state-of-the-etsreport/. Accessed 11 Sept 2020.

Marcu, A., Alberola, E., Caneill, J-Y., Mazzoni, M., Schleicher, S.P., Vailles, C., Stoefs, W., Vangenechten, D., \& Cecchetti, F. (2019). 2019 State of the EU ETS Report. Retrieved from: https://www.i4ce.org/download/2019-state-of-the-eu-etsreport/. Accessed 11 Sept 2020.

Ministry of Industry and Trade (2017). Vyhodnocení: Státního programu na podporu úspor energie a využití obnovitelných a druhotných zdrojů energie za rok 2016. Retrieved from: https://www.mpo-efekt.cz/upload/62d0d69c2bcb052223969 e1a31d35403/vyhodnoceni-statniho-programu-2016.pdf. Accessed 11 Sept 2020

Perino, G. (2018). New EU ETS Phase 4 rules temporarily puncture waterbed. Nature Climate Change, 8(4), 262-264.

Press Association (2019). Ireland to raise carbon tax to $€ 80$ per tonne, Taoiseach tells UN. Breaking News. Retrieved from: 
www.breakingnews.ie/ireland/ireland-to-raise-carbon-taxto-80-per-tonne-taoiseach-tells-un-952610.html. Accessed 11 Sept 2020.

Rabe, B. G. (2016). The durability of carbon cap-and-trade policy. Governance, 29(1), 103-119.

Rabe, B. G. (2018). Can We Price Carbon? MIT. Cambridge: University Press.

Raymond, L. (2016). Reclaiming the Atmospheric Commons: The Regional Greenhouse Gas Initiative and a New Model of Emissions Trading. MIT. Cambridge: University Press.

Regional Greenhouse Gas Initiative, Inc (2019). The Investments of RGGI Proceeds in 2017. Retrieved from: https://www. rggi.org/sites/default/files/Uploads/Proceeds/RGGI Proceeds_Report_2017.pdf. Accessed 11 Sept 2020.

Rosenow, J., \& Kern, F. (2017). EU Energy Innovation Policy The curious case of energy efficiency. In R. Leal-Arcas \& J. Wouters (Eds.), Research Handbook on EU energy law and policy. Cheltenham: Edward Elgar Publishing.

Rosenow, J., Graichen, J., \& Scheuer, S. (2018). Destination Paris: why the EU's climate policy will derail without energy efficiency. Retrieved from: http://www.raponline. org/knowledge-center/. Accessed 11 Sept 2020.

Sandbag (2017). An agenda for strategic reform of the ETS. Retrieved from: https://ember-climate.org/wpcontent/uploads/2017/12/Strategic-Reform-of-the-ETS2017-Sandbag-1.pdf. Accessed 11 Sept 2020.

Thema, J., Suerkemper, F., Couder, J., Mzavanadze, N., Chatterjee, S., Mzavanadaze, N., Chaterjee, S., Teubler, J.,
Thomas, S., Ürge-Vorsatz, D., Bo Hansen, M., Bouzarovski, S., Rasch, J., \& Wilke, S. (2019). The multiple benefits of the 2030 EU energy efficiency potential. Energies, 12(14), 2798.

Wiese, C., Cowart, R., \& Rosenow, J. (2018). Carbon leverage: Investing Europe's carbon revenues in energy efficiency. Retrieved from: https://www.raponline.org/knowledgecenter/. Accessed 11 Sept 2020.

Wiese C., Cowart, R., \& Rosenow, J. (2019). Auctioning revenues to foster energy efficiency: status quo and future potential within the European emissions trading system. ECEEE 2019 Summer Study. Retrieved from: https://www.eceee. org/library/conference_proceedings/eceee_Summer_ Studies/2019/. Accessed 11 Sept 2020.

Zámečník, M., \& Lhoták, T. (2012). Should the government invest in energy efficiency of buildings? Macroeconomic impact assessment [Executive Summary]. Retrieved from: http://www.buildup.eu/en/practices/publications/shouldgovernment-invest-energy-efficiency-buildingsmacroeconomic-impact. Accessed 11 Sept 2020.

Zeitung für Kommunale Wirtschaft (2018). Mittel des EKF werden nicht abgerufen. Retrieved from: https:/www.zfk. de/politik/deutschland/artikel/mittel-des-ekf-werden-nichtabgerufen-2018-04-20/.

Publisher's note Springer Nature remains neutral with regard to jurisdictional claims in published maps and institutional affiliations. 